\title{
Program RIAS (Remaja Siaga Asap Rokok): Mencegah dan Mengatasi Adiksi Rokok pada Remaja
}

\author{
Laili Rahayuwati, Mamat Lukman, Endah Rahayu, Muhamad Ridwan \\ Fakultas Keperawatan, Universitas Padjadjaran \\ Email: laili.rahayuwati@unpad.ac.id
}

\begin{abstract}
Abstrak
Global Youth Tubacco Survey (GYTS) menyatakan bahwa Indonesia sebagai negara dengan angka perokok remaja tertinggi tahun 2014, sebagian besar merupakan laki-laki dengan usia 12-13 tahun saat pertama kali merokok dan perempuan pada usia 14-15 tahun. Berdasarkan data yang ditujukkan oleh Kemenkes bahwa prevalensi remaja usia 16-19 tahun meningkat 3 kali lipat dari tahun 1995 dari 7,1\% menjadi 20,5\% di tahun 2014. Melihat dari hasil data tersebut. Kegiatan Pengabdian Pada Masyarakat ini bertujuan untuk mencegah dan mengatasi adiksi merokok pada remaja dengan menggunakan sebuah program yang menitikberatkan pada preventif dan kuratif yaitu dengan menggunakan progran inovasi RIAS (Remaja Siaga Asap Rokok). Jumlah partisipan dalam program ini adalah 35 siswa dan siswi. Program RIAS yang diberikan kepada peserta menggunakan metode forum group discusion, dimana peserta diberikan pretest dan post test untuk mengetahui tingkat pengetahuan mengenai merokok, dan diajak berdiskusi melalui pemutaran video dan tanya jawab melalui kelompok kecil yang didampingi oleh dua orang fasilitator. Kegiatan akhir review materi dan pengucapan ikrar RIAS yang diucapkan bersamasama. Simpulan adalah setelah berlangsungnya program RIAS, peserta meningkat pentingnya bahaya merokok dan pentingnya meningkatkan gerakan anti merokok sejak dini. Saran: perlunya dilakukan pengulagan secara regular program pencegahan merokok untuk menambah keyakinan diri remaja untuk berperilaku tidak merokok.
\end{abstract}

Kata Kunci: Fokus Group Discussion, remaja, Remaja Siaga Asap Rokok (RIAS), rokok.

\begin{abstract}
The Global Youth Tubacco Survey (GYTS) states that Indonesia as the country with the highest teenage smoking rate of 2014, is mostly male with age 12-13 years when first smoked and female at 14-15 years old. Based on data indicated by the Ministry of Health that the prevalence of adolescents aged 16-19 years increased 3-fold from 1995 from $7.1 \%$ to $20.5 \%$ in 2014. According to the result, this study aimed to prevent and address smoking addiction in adolescents by using a program that focuses on preventive and curative that is by using innovation program of RIAS (Remaja Siaga Asap Rokok). The participants who involved in the program were 35 students. The RIAS program given to the participants used the method of group discusion forums, where participants were given pretest and post test to know the level of knowledge about smoking, and were invited to discuss through played a video and discused in a small groups accompanied by two facilitators. The event ended with a material review and pronunciation of the RIAS pledge that was spoken together. Conclusion: After the ongoing program of RIAS, participants can realize the importance of the dangers of smoking and the importance of improving anti-smoking movement early on. Recommendation:There is needs of regular program for prevention smoking to adolescents.
\end{abstract}

Keywords: Adolescence, Focus Group Discussion, smoke. 
Laili Rahayuwati: Program RIAS (Remaja Siaga Asap Rokok): Mencegah dan Mengatasi Adiksi Rokok

\section{Pendahuluan}

Produk tembakau merupakan produk yang secara keseluruhan terdiri dari bahan tembakau, sebagai bahan bakunya dan diolah menjadi bahan yang bisa dibakar, dihisap dan atau dihirup asapnya (PP No 99 tahun 2002). Global Youth Tubacco Survey (GYTS) menyatakan bahwa Indonesia sebagai negara dengan angka perokok remaja tertinggi tahun 2014, sebagian besar laki-laki, pertama merokok pada usia 12-13 tahun dan untuk perempuan awal merokok usia 14-15 tahun (WHO, 2014). Data Kementerian Kesehatan menunjukkan peningkatan prevalensi perokok dari $27 \%$ pada tahun 1995 , meningkat menjadi 36,3\% pada tahun 2014. Artinya, jika 20 tahun yang lalu dari setiap 3 orang Indonesia 1 orang di antaranya adalah perokok, maka dewasa ini dari setiap 3 orang Indonesia 2 orang di antaranya adalah perokok.

Kebiasaan buruk merokok meningkat pada generasi muda. Data Kemenkes menunjukkan bahwa prevalensi remaja usia 16-19 tahun yang merokok meningkat 3 kali lipat dari 7,1\% di tahun 1995 menjadi 20,5\% pada tahun 2014. Dan yang lebih mengejutkan, adalah usia mulai merokok semakin muda (dini). Perokok pemula usia 10-14 tahun meningkat lebih dari 100\% dalam kurun waktu kurang dari 20 tahun, yaitu dari 8,9\% di tahun 1995 menjadi $18 \%$ di tahun 2013.

Berdasarkan kajian informasi wilayah Jawa Barat, khususnya di area PTN (Perguruan Tinggi Negeri) Universitas Padjadjaran ditemukan permasalahan siswa siswi perokok di Kabupaten Sumedang dan Kota Bandung. Secara spesifik, permintaan terhadap pengabdian masyarakat disampaikan oleh tokoh informal di wilayah Kota Bandung, khususnya Cisaranteun Kulon. Karena seringkali sasaran pengabdian masyarakat ditujukan ke kabupaten dan desa-desa, sehingga seringkali masalah di kota menjadi terabaikan. Untuk itu perlu suatu upaya awal untuk memberikan pletihan singkat pada remaja Cisaranteu tentang masalah rokok dan pencehagannya.

Berdasarkan uraian latar belakang yang telah dijelaskan tersebut, maka dirumuskan masalah yaitu "Bagaimana proses terlaksananya program RIAS (Remaja Siaga Asap Rokok) dalam upaya mencegah dan mengatasi Adiksi merokok pada remaja di Cisaranten Kulon?"

Tujuan kegiatan pengabdian pada masyarakat (PPM) melalui program RIAS ini adalah untuk mensintesis gagasan kreatif melalui sebuah program inovasi dengan menitikberatkan pada usaha preventif dan promotif dalam mencegah dan mengatasi 
adiksi merokok pada remaja. Adapun pilihan program RIAS berdasar kajian bahwa kebutuhan remaja terhadap informasi harus diberikan. Dan bentuk pemberian informasi ini harus sesuai dengan kebutuhan sasaran baik dari sisi metode dan strategi. Sehingga dibuatlah kelompok kecil group mahasiswa untuk menggali keinginan remaja terhadap bentuk pemberian informasi yang sifatnya informal namun akan berdampak pada perubahan pengetahuan dan sikap dalam jangka awal dan perubahan perilaku dalam jangka Panjang. Bentuknya adalah memberikan pelatihan singkat pada siswa siswa sebagai peer group di lingkungan masayarakat untuk melakukan transfer pengetahuan dan perilaku.

\section{Metode}

Pelaksanaan kegiatan dilakukan melalui pendidikan kesehatan. Subjek dalam kegiatan pengabdian pada masyarakat ini adalah remaja yang tinggal di daerah Cisaranten. Khususnya terdapat 35 remaja yang umumnya terdiri dari siswa dan siswi SD, SMP, SMA dari rentang 9-18 tahun, baik terdiri dari laki-laki mupun perempuan. Fokus pada kegiatan pengabdian pada masyarakat ini adalah memberikan intervensi untuk pencegahan merokok.

Penentuan lokasi kegiatan ini di Masjid Al-Muhajirin Wal Nashor Jalan Cisaranten Kulon I, Cisaranten Kulon, Arcamanik, Kota Bandung pukul 09.00-selesai. Sasaran kegiatan adalah anak usia SD, SMP, SMA. Alasan pilihan sasaran mulai SD karena perilaku merokok pada remaja sekarang ini semakin memprihatinkan dan tampak sudah menjadi trend di kalangan pelajar baik SMP maupun SMA, bahkan sebagian kecil siswa SD juga telah menunjukkan adanya perilaku merokok.

Dalam kegiatan pengabdian masyarakat ini dilaksanakan Focus Group Discussion, dimana menurut Nyumba, et.al (2018), FGD adalah metode eksplorasi suatu isu/fenomena khusus dari suatu kelompok individu yang berfokus pada aktivitas bersama diantara para individu yang terlibat didalamnya untuk menghasilkan suatu kesepakatan bersama. Metode FGD merupakan salah satu metode pengumpulan informasi atau penyampaian pendidikan dengan hasil akhir memberikan data yang berasal dari hasil interaksi sejumlah partisipan dalam suatu kegiatan. Data yang diperoleh di analisis menggunakan metode deskriptif kualitatif, yaitu suatu cara menarik kesimpulan dengan menjabarkan atau mendeskripsikan data-data yang diperoleh dalam 
Laili Rahayuwati: Program RIAS (Remaja Siaga Asap Rokok): Mencegah dan Mengatasi Adiksi Rokok

bentuk kalimat-kalimat yang akhirnya bisa dijadikan untuk menarik hasil berupa kesimpulan. FGD digunakan dalam melengkapi metode lain untuk pelaksanaan intervensi.

Teknik analisis data yang digunakan adalah dengan dinyatakan dalam bentuk simbolik, seperti pernyataan, tafsiran, tanggapan, lisan maupun tanggapan nonverbal. Pada tahap selanjutnya dilakukan kegiatan pengukuran melalui proses pengumpulan data kemudian di analisis dan disajikan dalam laporan.

Satu hari sebelum pelaksanaan, beberapa tim pelakasana mendiskusikan secara teknis acara yang telah dibuat. Selain itu dilaksanakan briefing memastikan persiapanpersiapan yang sudah dilaksanakan untuk hari pelaksanaan. Dalam mempersiapkan kegiatan RIAS ini terjadi beberapa kendala seperti rundown yang diubah tengah malam karena terjadi kesalahan waktu, sehingga MC membuat empat rencana untuk rundown, namun hal-hal terkait rundown tersebut dapat diatasi.

Kegiatan ini ditulis berdasarkan rincian waktu yang telah dilaksanakan sesuai dengan rundown dan rencana yang telah ditentukan. Kegiatan dimulai pukul 9.00-11.40 WIB. Pukul 09.00-09.05 kegiatan dibuka oleh Master Ceremony (2 orang) dan dilanjutkan dengan tilawah surat Al-Baqarah ayat 168. Kemudian pada pukul 9.00-9.05 ini MC juga memperkenalkan program RIAS dan berkata bahwa "teman-teman disini adalah anak-anak terpilih yang menyuarakan suara anti rokok", selain itu MC juga memperkenalkan jargon dari program RIAS, jargonnya adalah ketika MC berkata RIAS 2017, anak-anaknya menjawab Remaja Siaga Asap Rokok dengan gerakan-gerakan tertentu.

Pukul 09.05-09.10 sambutan oleh pihak akademisi dari Fakultas Keperawatan Unpad. Pukul 09.10-09.15 barulah dilaksanakan sambutan oleh tokoh masyarakat (karena tokoh masyarakat baru datang beberapa saat kemudian). Tokoh masyarakat yang datang adalah ketua RT 09 di Cisaranten. Sehingga pukul 09.15-09.25 acara langsung dilanjut ke games yang bernama dor dor aw, games ini dipimpin oleh 2 orang mahasiswa, teknis games ini yaitu semua anak-anak berdiri melingkar lalu di dada mereka ditempel kertas yang bertuliskan masing-masing dari nama mereka, jika pemimpin games menyebut nama salah satu dari mereka maka teman yang sebelah kanan dan kiri nya harus saling tembak jika telat maka kalah dan keluar. Pemenang games diberi hadiah berupa snack dan payung. 
Laili Rahayuwati: Program RIAS (Remaja Siaga Asap Rokok): Mencegah dan Mengatasi Adiksi Rokok

Tak terasa games pun selesai, respon anak-anak tersebut terlihat antusias, tidak ada yang diam tidak mengikuti gamesnya. Rangkaian acara pun dilanjut pukul 09.2509.35 dilaksanakan pretest tentang pengetahuan mereka terkait rokok. Soal pretest ini berisi 16 butir pertanyaan dimana setiap butirnya memberikan pilihan sangat stidak setuju, tidak setuju, sangat setuju dan setuju. Peserta terlihat serius mengerjakannya dan mengerjakan sesuai kemampuan mereka tanpa contek kiri kanan.

Setelah selesai melaksanakan pretest, pada pukul 09.35-09.50 acara dilanjut dengan menampilkan tiga video yang berisi tentang kandungan yang terdapat dalam satu batang rokok, fenomena rokok di Indonesia serta bahaya yang ditimbulkan dari merokok (baik perokok aktif ataupun perokok pasif). Ketika penayangan video, peserta antusias menyaksikan namun terlihat ada yang belum paham karena salah satu video memakai bahasa Inggris.

Setelah ditampilkannya video, pukul 09.50-10.10 acara dilanjut dengan diskusi (focus group discussion) tentang pengetahuan peserta terkait rokok, diskusi dilaksanakan dengan dibagi dua kelompok kecil, satu kelompok berjumlah 12 orang yang didampingi fasilitator dua orang mahasiswi serta satu kelompok lagi berjumlah 11 orang yang didampingi oleh dua orang mahasiswi. Dalam forum FGD ini fasilitator berdiskusi dengan peserta sambil bertanya. Hasil diskusi menunjukan bahwa peserta dapat menjawab pertanyaan terkait rokok yang diberikan oleh fasilitator. Secara umum pengatahuan mereka tentang bahaya rokok ini sudah baik. Ada salah satu peserta yang bercerita bahwa di sekolahnya juga sudah beberapa kali diberi tahu tentang rokok dan bahayanya, namun tetap saja lingkungan tidak mendukung. Seperti masih ada guru yang merokok di depan muridnya dan tidak ditegur.

Sesi diskusi pun selesai pukul 10.10, kemudian dilanjut pukul 10.10-10.30 yaitu review dan penayangan kembali video karena dirasa penayangan video sebelumnya belum jelas. Penayangan kembali tersebut dilakukan oleh narasumber kedua untuk lebih memperkuat materi. "lebih baik nanti pas review sekalian untuk penayangan video, karena dirasa penayangan video tadi belum jelas terlebih ada video yang memakai bahasa Inggris." Akhirnya video pun ditayangkan kembali namun seperti di periode seperti itu dan dijelaskan ulang oleh narasumber kedua sambil mereview apa yang didiskusikan peserta bersama fasilitatornya dengan bahasa yang lebih sederhana. Contoh ketika narasumber menjelaskan kembali tentang bahaya merokok dengan 
mengibaratkan efek jelek dari racun tikus. Respon dari peserta terlihat baik dan antusias serta memperlihatkan bahwa program ini menambah pengetahuan mereka. Seperti bahaya merokok apa saja, secara umum peserta dapat mereview kembali. Selain itu, untuk peserta yang berani menjawab ketika ditanya oleh narasumber diberi hadiah. Hadiah tersebut berupa satu paket makanan yang berisi wafer, susu, biskuit dan wafer roll serta payung.

Akhirnya review pun selesai, namun review baru selesai pukul 10.40, awalnya setelah review akan dilanjutkan oleh posttest. Namun, ada perubahan karena dirasa lebih baik jika setelah review langsung diucapkan sebuah ikrar untuk peserta yang menggambarkan bahwa merekalah remaja anti rokok. Ikrar tesebut dipimpin oleh narasumber (baik akademisi maupun praktisi perawat) langsung. Jadi, narasumber menyebutkan dahulu ikrarnya lalu diikuti oleh para peserta. Ikrar yang diucapkan berbunyi: "1. Kami remaja Cisaranten penerus bangsa tidak akan mencoba dan memulai untuk merokok. Merokok tidak baik untuk kesehtaan diri sendiri dan orang sekitar kita serta dapat merusak generasi penerus bangsa; 2. Demi masa depan yang lebih cemerlang kami akan selalu berperilaku hidup bersih dan sehat sehingga akan terwujud generasi muda yang sehat, berkualitas dan berprestasi.”. Ikrar tersebut diucapkan satu kali dengan posisi peserta sambil berdiri dan penuh semangat.

Review dan ikrar pun selesai pukul 11.00-11.10 WIB, pukul 11.10 acara dilanjutkan dengan posttest. Soal posttest sama dengan soal pretest sebelumnya, peserta terlihat serius mengerjakan posttest yang diberikan. Setelah posttest selesai diberikan, peserta diberi gantungan kunci tanda bahwa mereka sudah terpilih sebagai remajaremaja yang menyuarakan tentang asap rokok.

Akhirnya pada pukul 11.10 pun posttest selesai. Pukul 11.10-11.20 WIB kegiatan program RIAS ini dilanjutkan oleh asik-asikan dengan peserta, seperti menantang peserta siapa yang berani menyimpulkan hasil dari kegiatan ini, komitmen mereka setelah mendapat pengetahuan di program RIAS ini dan yang berani untuk menyampaikan kesan pesan dari program RIAS ini, dan yang berani untuk melakukan hal-hal tersebut diberi hadiah satu paket makanan dan satu buah payung. Pada bagain ini peserta terlihat begitu antusias untuk menyampaikannya. Dibuktikan dengan mereka berebut mengacungkan tangan agar dapat menjawabnya. Dan akhirnya hadiah pun habis dibagikan, tinggal bersisa 3 buah payung. Pukul 11.20, kegiatan dilanjut dengan ice 
Laili Rahayuwati: Program RIAS (Remaja Siaga Asap Rokok): Mencegah dan Mengatasi Adiksi Rokok

breaking (sejenis gerakan bersama-sama dengan peserta) yaitu gerakan babby shark dan senam pinguin yang dipimpin oleh seorang pemandu mahasiswa. Tiga orang yang berani mempimpin barisan depan lah yang mendapat payung tadi. Peserta terlihat antusias dalam bergerak bersama.

Pukul 11:35 setelah selesai untuk bergerak bersama dengan gerakan babby shark dan senam pinguin, kegiatan pun ditutup dengan doa. Dan akhirnya kegiatan RIAS ini resmi ditutup pukul 11:40 WIB pas adzan dzuhur. Sebelum semua bubar dan beranjak dari tempat, kegiatan diakhiri oleh sesi foto bersama dengan peserta. Selama beberapa dari kami melaksanakan kegiatan di dalam madrasah, beberapa dari kami juga menyebar kuisioner ke warga terkait pengetahuan mereka tentang rokok.

Sebagai bentuk evaluasi, selama tahap persiapan kegiatan program RIAS, dilaksanakan pertemuan dengan para narasumber terkait tempat pelaksanaan pogram RIAS dan teknis kegiatan tersebut. setelah itu semua kelompok berkumpul untuk mendiskusikan terkait teknis, persiapan logistik dan konsumsi. Pertemuan tersebut dilaksanakan pada hari Rabu, 6 Desember 2017 dengan agenda membahas konsep dan pembagian jobdesk. Sesuai dengan rencana pelaksanaan program RIAS diadakan tanggal 10 November 2017. Namun, karena adanya kegiatan Maulid Nabi di Masjid AlMuhajirin Wal Anshor, Cisaranten Kulon. Sehingga remaja-remaja setempat tidak bisa menghadiri acara RIAS karena itulah kegiatan ini diundur menjadi tanggal 17 Desember 2017. Untuk teknis acara pun berubah, awalnya kami hanya meminta 20 orang remaja yang menjadi responden sehingga teknik acaranya hanya ada 1 kelompok besar saja, setelah mendapatkan data dari bapak RT setempat ternyata jumlah remaja yang terdaftar 35 orang sehingga teknis acara nya pun dibagi menjadi 3 kelompok kecil.

\section{Hasil}

Peserta yang hadir berjumlah 23 orang dengan karakteristik: 1) laki-laki dan perempuan dengan rentang usia 9-18 tahun; 2) Laki-laki berjumlah 12 orang; 3) Perempuan berjumlah 11 orang; 4) Sebagian besar dari mereka adalah siswa-siswi SMP.

Dari kegiatan yang telah dilaksanakan, program terlaksana dengan baik dan lancar. Namun pada pelaksanaan nya terdapat beberapa kendala, saat pemutaran video mengenai bahaya rokok, remaja kurang memahami isi dari video tersebut dikarenakan video yang ditayangkan di layar proyektor tidak terlihat jelas karena cahaya matahari 
Laili Rahayuwati: Program RIAS (Remaja Siaga Asap Rokok): Mencegah dan Mengatasi Adiksi Rokok

yang masuk ke ruangan terlalu menyilaukan. Akhirnya setelah kegiatan peer education, diputarkan kembali video melalui laptop agar remaja dengan jelas menonton video tersebut dan beliau berdiskusi dengan remaja mengenai pendapat remaja mengenai bahaya rokok, kesan-pesan mengikuti kegiatan ini dan manfaat nya. Ketika pelaksanaannya, peserta yang datang bukan hanya remaja saja tetapi ada beberapa peserta yang masih duduk di sekolah dasar sehingga seluruh tim harus menyesuaikan materi yang disampaikan agar dapat di terima oleh seluruh peserta.

Secara umum, pada awal program RIAS pengetahuan siswa dan siswi tentang merokok hanyalah sebatas informasi dari media yang didapatkan secara umum tanpa ada filter manakah informasi yang tepat dan tidak. Sebagian besar remaja tidak mengetahui dengan spesifik efek merokok dan kerugian berperilaku merokok. Hal ini ditunjukkan pada saat pelaksanaan awal dan disukusi ada beberapa pertanyaan yang menunjukkan bahwa informasi yang diahami oleh remaja tentang rokok dan pencegahan sangat terbatas. Beberapa pernyataan remaja menunjukkan bahwa faktor keluarga dan lingkungan juga penting dalam menentukan apakah seseorang tersbut akan menjadi perokok atau tidak.

Remaja yang berada di lokasi tersebut sudah memahami dampak buruk asap rokok bagi kesehatan. Namun beberapa dari mereka hanya paham bahwa asap rokok hanya berbahaya bagi perokok aktif sedangkan mereka belum mengetahui dampak bagi perokok pasif. Ada beberapa peserta yang memahami tentang bahaya rokok bagi perokok aktif dan pasif, serta mengetahui bahwa asap rokok dampaknya jauh lebih berbahaya bagi perokok pasif.

Setelah diberikan intervensi dengan menonton video tentang bahaya merokok dan melakukan tanya jawab dengan fasilitator, hampir seluruh peserta memahami bahaya asap rokok bagi kesehatan. Peserta awalnya tidak mengerti isi dari video yang diberikan namun setelah diberikandan penjelasan mengenai isi video yang ditayangkan, peserta akhirnya memahami bahwa asap rokok memang sangat berbahaya bagi kesehatan perokok aktif maupun perokok pasif.

Setelah pelaksanaan intervensi maka ditutup dengan ikrar, bertujuan untuk menguatkan keyakinan dan motivasi dalam melawan keinginan merokok, serta mampu menyampaikan keinginan untuk selalu berusaha terhindar dari perilaku merokok. Dan 
Laili Rahayuwati: Program RIAS (Remaja Siaga Asap Rokok): Mencegah dan Mengatasi Adiksi Rokok

ikrar adalah sebagai bagian penguatan melaui pengucapan lisan partisipan untuk dapat digunakan dalam membentuk keyakinan diri yang kebih kuat.

\section{Pembahasan}

Akibat buruk kebiasaan merokok bagi kesehatan telah banyak di bahas. Hasil penelitian di Inggris menunjukkan bahwa kurang lebih 50\% para perokok yang merokok sejak remaja akan meningggal akibat penyakit-penyakit yang berhubungan dengan kebiasaan merokok. Kebiasaan merokok telah terbukti berhubungan dengan kurang lebih 25 jenis penyakit dari berbagai organ tubuh manusia. Penyakit tersebut, antara lain: kanker mulut, esophagus, faring, laring, paru, pancreas, kandung kemih, dan penyakit pembuluh darah. Hal itu dipengaruhi pula oleh kebiasaan meminum alkohol serta faktor lain (Aditama, 1995). Umumnya, remaja yang mendapatkan pendidikan kesehatan tidak banyak mengetahui informasi dan pengetahuan tersebut.

Perokok dapat dikategorikan sebagai tiga kelompok, yaitu perokok aktif, perokok pasif, dan perokok ketiga (benda yang dapat menyimpan residu asap rokok). Menjadi perokok pasif adalah salah satu hal yang harus dihindari oleh anak-anak karena dapat merusak organ tubuh mereka, tetapi sayangnya masih banyak anak-anak di Indonesia yang orangtuanya tidak menyadari hal ini.

Dampak sosial saat menjadi perokok adalah asap yang dihasilkan dari rokok menyebabkan polusi khususnya di ruangan yang tertutup atau di dalam mobil sehingga asapnya mengganggu. Berada pada suatu ruangan tertutup bersama orang yang merokok sama halnya dengan menghisap sepuluh batang rokok. Perokok yang terserang TBC, Influenza atau lainnya bisa menularkannya lewat batuk. Dampak asap rokok dan rokok diketahui oleh sebagian remaja namun tidak spesifik.

Secara ekonomi merokok merupakan perbuatan menghambur-hamburkan harta tanpa manfaat disampaikan oleh beberapa remaja di Cisaranteun. Anggap saja penduduk Indonesia berjumlah 8.000 .000 jiwa, sementara 1.000 .000 jiwaadalah seorang perokok. Apabila masing-masing perokok menghabiskan uang sebanyak10.000 rupiah setiap hari, maka dalam sehari sebanyak 10.000.000.000 rupiah dihabiskan oleh 1.000.000 jiwa. Dengan demikian 3.600.000.000 rupiah dihabiskan oleh setiap orangdalam 1 tahun terbuang percuma. Ini masih belum ditambah dengan 
korek api (gas) yang mahal untuk menyulut rokok. Belum lagi dengan biaya bila perawatan kesehatan akibat prilaku merokok.

Dampak sosial bagi yang kecanduan rokok juga dipahami oleh sebagian siswa siswa partisipan dengan menyatakan bahwa efek kebiasaan merokok dan kebutuhan terhadap uang untuk membeli rokok juga dilakukan dengan banyak cara, terkadang mencuri uang orang tuanya atau tetangganya hanya untuk membeli rokok. Lebih lanjut, berdasarkan data dari pengadilan, sembilan puluh limapersen pelaku tindakan kriminal adalah para perokok. Terdapat kecenderungan rokok bisa menegangkan saraf. Oleh karena itu para perokok sangat mudah untuk marah, bertengkar, mencuri dan melakukan kekerasan. Berdasarkan beberapa kajian maka diperlukan suatu pembangunan karakter untuk membina generasi mudah dari perilaku merokok (Giannakupolous, et.al. 2010; Hammado, 2014).

Program pencegahan merokok yang dilakukan secara regular bisa menyadarkan dan mengingatkan kembali tentang pentingnya waspada terhadap rokok dan asap rokok. Oleh karena itu dirasa penting untuk bekerjasama dengan program lintas sektor secara komprehensif agar kegiatan prevensi bisa menjadi suatu strategi yang tepat untuk menghindarkan remaja dari perilaku merokok.

\section{Simpulan}

Berdasarkan program pengabdian masyarakat yang dilakukan di desa Cisaranteun dengan tema "RIAS" peneliti merumuskan beberapa simpulan tentang pencegahan asap rokok pada remaja dapat membantu menyadarkan remaja tentang bahaya merokok dan oentingnya oencegahan merokok di lingkungan mereka.

Selanjutnya pada saat kegiatan evaluasi, peserta dapat menjawab dan menjelaskan bahaya dari asap rokok dengan baik. Peserta juga membacakan ikrar remaja siaga asap rokok bersama-sama dengan peneliti secara antusias, sebagai bentuk komitmen dan dikukuhkannya mereka menjadi duta remaja siaga asap rokok. Peserta sudah memahami bahwa gerakan anti rokok harus dimulai sejak dini karena sasaran produsen rokok sekarang adalah anak-anak remaja yang masih mencari jati diri.

Saran yang bisa dipertimbangkan yaitu: 1) Perlunya sosialisasi pada setiap sekolah, dan masyarakat mengenai bahaya dari rokok dan diterapkan sanksi yang tegas 
Laili Rahayuwati: Program RIAS (Remaja Siaga Asap Rokok): Mencegah dan Mengatasi Adiksi Rokok

untuk siswanya yang merokok; 2) Perlu dukungan dari semua pihak, baik pihak keluarga, guru maupun teman sebayanya untuk tidak merokok di depan anak remaja.

\section{Ucapan Terima Kasih}

Kepada Yayasan Nursentra di Cisaranteun Kulon beserta seluruh mahasiswa Fakultas Keperawatan yang terlibat dalam kegiatan pelaksanaan PPM ini, yaitu: Asep Solahudin, Nelawati Rafika Dita Martiana, Witri Destiani, Rizka Ananda Rahmatunnisa, Gisela Rizki Fauziah, Alifa Rufaida, Nabila Pasha Amelia, Noviyanti Nurrahmah, Evita Rahmawati Miliarta.

\section{Daftar Pustaka}

Aditama, Tjandra Y. 1995. Proses Berhenti Merokok. Jakarta: Cermin Dunia. Kedokteran.

Giannakopoulos, G, Chara Tzavara, Christine Dimitrakaki, Gerasimos Kolaitis, Vasiliki Rotsika and Yannis Tountas. (2010). Emotional, behavioural problems and cigarette smoking in adolescence: findings of a Greek cross-sectional study. BMC Public Health. https://doi.org/10.1186/1471-2458-10-57.

Hammado, N. (2014). Pengaruh Rokok Terhadap Kesehatan dan Pembentukan Karakter Manusia. Jurnal Kedokteran dan Farmasi, Volume 1 Nomor 1, 77-84.

Nyumba, Tobias O, Kerrie Wilson, Christina J. Derrick, Nibedita Mukherjee. (2018). The use of focus group discussion methodology: Insights from two decades of application in conservation. British Ecological Societ. https://doi.org/10.1111/2041-210X.12860. 